\title{
Isolation, Partial Purification and Characterization of Polyphenol Oxidase from Two Species of African Mango Seeds (Irvingia gabonensis and Irvingia wombolu)
}

\author{
David Morakinyo Sanni \\ Department of Biochemistry, Federal University of Technology, Akure, Nigeria \\ Email address: \\ moraksanni@yahoo.co.uk
}

\section{To cite this article:}

David Morakinyo Sanni. Isolation, Partial Purification and Characterization of Polyphenol Oxidase from Two Species of African Mango Seeds (Irvingia gabonensis and Irvingia wombolu). Advances in Biochemistry. Vol. 4, No. 4, 2016, pp. 47-52. doi: $10.11648 /$ j.ab.20160404.12

Received: May 16, 2016; Accepted: May 26, 2016; Published: June 30, 2016

\begin{abstract}
Polyphenol oxidases are oxido-reductases that catalyses oxidation of phenolic compounds in the presence of oxygen to form corresponding quinone intermediates which spontaneously polymerize to form undesirable pigments. Polyphenol oxidase was isolated and characterized in Irvingia species (gabonensis and wombolu) kernel, a tropical African fruit. Extracts were partially purified with ammonium sulphate. The effects of optimum $\mathrm{pH}$ and temperature were investigated while the $\mathrm{pH}$ and thermal stability were carried out. The $\mathrm{K}_{\mathrm{m}}, \mathrm{V}_{\max }$ and the activity on both monophenol and diphenol substrates were determined. The optimum $\mathrm{pH}$ and optimum temperature of activity were found out to be 7.0 and $60^{\circ} \mathrm{C}$ in both species. The enzyme was stable at $\mathrm{pH} 7.0$ and $\mathrm{pH} 8.0$, and also at temperatures of $25,30,40,50$ and $60^{\circ} \mathrm{C}$, it however loses stability beyond $60^{\circ} \mathrm{C} . \mathrm{K}_{\mathrm{m}}$ and $\mathrm{V}_{\max }$ for Irvingia gabonesis were $2.51 \mathrm{mM}$ and $0.0411 \mathrm{Unit} / \mathrm{min}$ while $\mathrm{K}_{\mathrm{m}}$ and $\mathrm{V}_{\max }$ for Irvingia wombolu were $2.55 \mathrm{mM}$ and $0.0415 \mathrm{Unit} / \mathrm{min}$ respectively. Higher activity was observed with diphenol substrate L-DOPA than with monophenol - tyrosine. It can therefore be deduced from this study that the storage of the seeds of African mango at a room temperature above $60^{\circ} \mathrm{C}$ will prolong its shelf-life.
\end{abstract}

Keywords: Enzyme Activity, African Mango, Polyphenol Oxidase

\section{Introduction}

Polyphenol oxidase (PPO; EC 1.10. 3.1) is widely found in nature [37]. It is typically present in majority of plant tissues $[40,31]$. Fruits and vegetables frequently undergo browning as a consequence of mechanical injury suffered during harvest, transport, storage and processing. Browning is attributed to the oxidation of phenolic substances by the enzyme polyphenol oxidase to quinones and their eventual polymerization to melanin pigments $[29,37]$. Due to its involvement in adverse browning of plant products, polyphenol oxidase has received much attention from researchers in the fields of plant physiology and food science.

The oxidative browning reactions in many foods of plant origin generally cause deterioration in food quality by changing nutritional and organoleptic properties [21]. These reactions significantly diminish consumer's acceptance, storage life and value of the plant product. Thus highly prized and economically valuable products are extremely vulnerable to deteriorative enzymatic browning also referred to as melanosis. Owing to its tremendous economic impact to the food industry, inhibition of polyphenol oxidase in food product has been widely studied [15].

It was suggested that polyphenol oxidase might be involved in the development of necrosis around damaged leaf surface and in defence mechanism against insects and plant pathogen attack [3] while melanin biosynthesized in animals mainly by polyphenol oxidase acts as a skin and hair pigment-protecting agent against harmful solar radiation [12].

Irvingia gabonensis and Irvingia wombolu are highly valuable and extensively utilised tropical African trees. An important food product in Africa is the Irvingia gabonensis, commonly known as "African mango", "Dika nut" or "bush mango". The juicy fruit pulp of Irvingia gabonensis is rich in vitamin $\mathrm{C}$ and it is widely reported to be consumed as a dessert fruit or snack throughout Western and Central Africa [9,33]. 
The kernels of Irvingia gabonensis is classed as an oilseed. They are grounded with pestle and mortar or on a stone into a paste or cake called 'dika bread', which is used as soup, stew or sauce additive, for flavouring and thickening [1, 17]. The kernels are highly valued for the slimy consistency they produced. Okafor [24] notes that whilst kernels from Irvingia spp. are used in soup making, Dika bread may be sun-dried so that it can be stored [34]. Irvingia kernels form an important part of the West and Central African diet, providing carbohydrate and protein [25]. Agbor [1] reports that the kernels may be roasted to enhance their flavouring effect, and that crushed pieces of the roasted kernels may be used in frying vegetables. Fat extracted from the kernels could be used for food applications, such as in margarine or cooking oil, and it is also suitable for soap, cosmetics and pharmaceuticals [8]. Flour produced by milling the seed testa has been used in feeds formulation for livestock [9]. Proper understanding of the polyphenol oxidase from African mango would go a long way in the development of enhanced storage techniques and in the utilization of commercial food processor.

\section{Materials and Methods}

\subsection{Sample Collection}

African mango (Irvingia gabonensis and Irvingia wombulu) seed both commonly known as "Dika nut" were bought from Oja Oba market in Akure, Ondo State of Nigeria.

\subsection{Preparation of Crude Extract}

African mango seeds, $45 \mathrm{~g}$ of each species was thoroughly homogenized in $450 \mathrm{ml}$ of ice cold $25 \mathrm{mM}$ phosphate buffer (pH 6.8) containing $10 \mathrm{mM}$ ascorbic acid using a warring blender for $3 \mathrm{~min}$ with 60 seconds resting period to avoid local elevation in temperature. The mixture was filtered using four layers of cheese cloth. The filtrate obtained was centrifuged in a refrigerating centrifuge at 6,000rpm for 30 $\min$ at $4{ }^{\circ} \mathrm{C}$. The supernatant obtained was stored in a refrigerator and used as crude extracts for further studies.

\subsection{Partial Purification of Polyphenol Oxidase from Irvingia Species}

The supernatant obtained from each species was brought to $80 \%$ Ammonium sulphate $\left[(\mathrm{NH} 4)_{2} \mathrm{SO}_{4}\right]$ saturation with solid Ammonium sulphate. The precipitated enzyme (polyphenol oxidase) was separated by centrifugation at $6,000 \mathrm{rpm}$ for 30 minutes. The precipitate was dissolved in small amount of $0.1 \mathrm{M}$ phosphate buffer ( $\mathrm{pH}$ 6.8) and dialyzed at $4^{\circ} \mathrm{C}$ overnight with three changes of buffer.

\subsection{Determination of Polyphenol Oxidase Activity}

Polyphenol oxidase activity was determined by measuring the initial rate of quinone formation, as indicated by an increase in absorbance at $475 \mathrm{~nm}$ [5]. One unit of enzyme activity was defined as the amount of enzyme that caused a change in absorbance of 0.001 per minute. The sample cuvette contained $0.7 \mathrm{ml}$ of $10 \mathrm{mM} 3$,4-dihydrophenylalanine solution in $0.1 \mathrm{M}$ phosphate buffer ( $\mathrm{pH} 6.8$ ) and $0.3 \mathrm{ml}$ of the enzyme solution while the blank contained only $0.7 \mathrm{ml}$ of $10 \mathrm{mM} \mathrm{3,4-}$ dihydrophenylalanine and $0.3 \mathrm{ml}$ of $0.1 \mathrm{M}$ buffer solution.

\subsection{Effect of pH on Polyphenol Oxidase Activity}

The effect of $\mathrm{pH}$ on polyphenol oxidase was investigated using $\mathrm{pH}$ range of $\mathrm{pH} 4.0-9.0,0.1 \mathrm{M}$ acetate buffer $(\mathrm{pH} 4.0$ 5.0), 0.1 M phosphate buffer ( $\mathrm{pH} 6.0-7.0)$ and $0.1 \mathrm{M}$ Tris/HCl buffer ( $\mathrm{pH}$ 8.0-9.0). Each of the buffer solution was used to prepare the substrate used in determining the activity of the enzyme at a particular pH. Enzymatic activity was measured according to the standard assay procedures.

\subsection{Effect of Temperature on Polyphenol Oxidase Activity}

The assay mixture was incubated at different temperatures varying from 30 to $80^{\circ} \mathrm{C}$ for $10 \mathrm{mins}$ in a regulated water bath. The activity assay was determined at $10^{\circ} \mathrm{C}$ temperature interval while the enzymatic activity under each temperature condition was expressed in relative form as the percentage of the highest activity reached.

\subsection{Effect of pH Stability on Polyphenol Oxidase}

The effect of $\mathrm{pH}$ on the stability of the enzyme was carried out by incubating the enzyme in a buffer solution at different $\mathrm{pH}$ in room temperature. Four fold dilution of the enzyme was prepared using the buffer solution. Enzymatic activity was determined at 0 mins and at 1hour interval for six hours period using the standard assay procedure.

\subsection{Thermal Stability}

Thermostability of polyphenol oxidase was investigated using the enzyme solution incubated for 1 hour in regulated Gallenkamp water bath at a particular temperature within the temperature range of 30 to $80^{\circ} \mathrm{C}$ at $10^{\circ} \mathrm{C}$ interval. Aliqout was withdrawn and cooled for the determination of enzyme activity at $10 \mathrm{mins}$ interval.

\subsection{Kinetic Parameters}

Polyphenol oxidase activities were determined using varying concentration of dihydrophenylalanine under standard conditions. Michaelis constant $\left(\mathrm{K}_{\mathrm{m}}\right)$ and maximum velocity $\left(\mathrm{V}_{\max }\right)$ was measured using the double reciprocal plot.

\subsection{Protein Determination}

Protein concentration was measured in all the stages of purification according to the method of Lowry et al., [19] using bovine serum albumin (BSA) as a standard.

\section{Results}

\subsection{Activity of Enzyme}

The activities of the crude enzyme of the two species were 86.4 and 100 units $/ \mathrm{ml}$ while the activities of the partially 
purified were 34 and 40 units $/ \mathrm{ml}$ for gabonensis and wombolu respectively. The protein contents of the partially purified Irvingia gabonensis and Irvingia wombolu were $1.6 \mathrm{mg} / \mathrm{ml}$ and $1.0 \mathrm{mg} / \mathrm{ml}$ while the specific activities were 4.1 and $2.13 \mathrm{units} / \mathrm{ml} / \mathrm{mg}$ respectively.

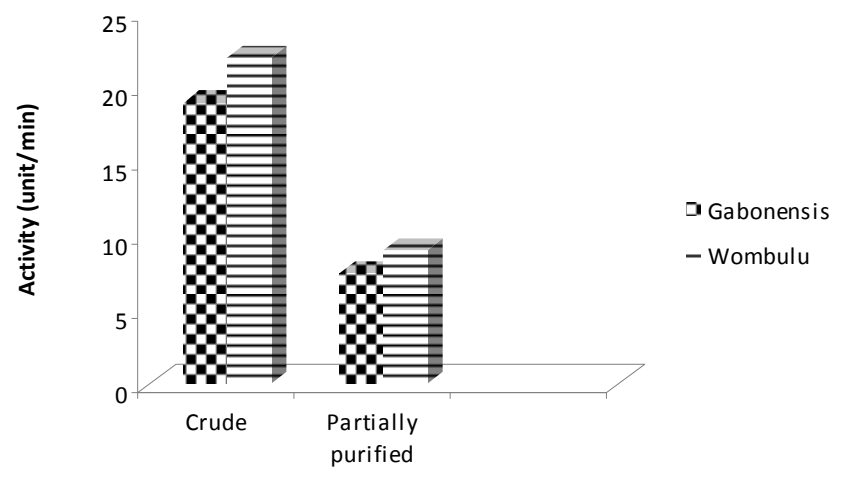

Figure 1. Activity of Crude and partially purified Polyphenol oxidase from Irvingia species.

\subsection{Effect of Temperature on the Activity of Polyphenol Oxidase}

Optimal temperature of $60^{\circ} \mathrm{C}$ was observed for polyphenol oxidase activity of both Irvingia gabonensis and Irvingia wombolu. The same pattern of a steady increase in activity of polyphenol oxidase was observed in both Irvingia gabonensis and Irvingia wombolu as the assay temperature was increased, until an optimal temperature was reached followed by a gradual decrease in the enzyme activity after $60^{\circ} \mathrm{C}$ as shown in figure 2. for gabonensis and wombolu.

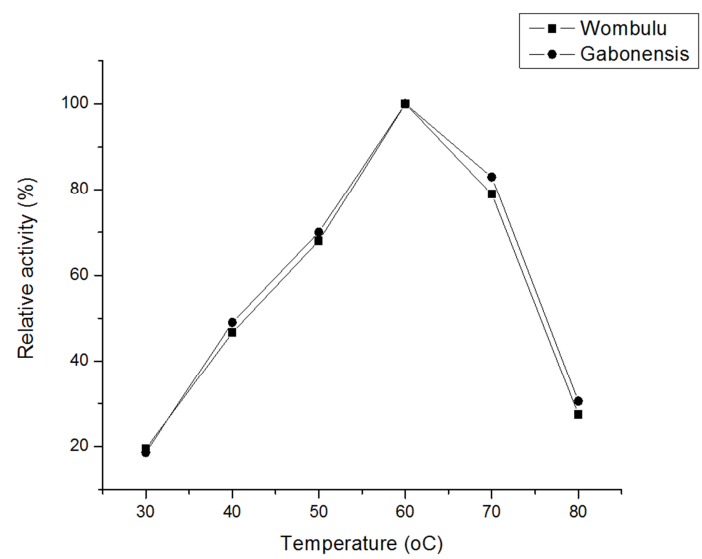

Figure 2. Effect of Temperature on the activity of Irvingia gabonensis and Irvingia wombolu polyphenol oxidase.

\subsection{Effect of pH on the Activity of Polyphenol Oxidase}

The effect of $\mathrm{pH}$ on the activity of partially purified polyphenol oxidase from Irvingia gabonensis and wombolu are illustrated in figure 3 . The enzyme showed activity in all the $\mathrm{pH}$ investigated, $(\mathrm{pH} 4.0-9.0)$. The enzyme from the two species gave an optimal $\mathrm{pH}$ at $\mathrm{pH}$ 7.0. The figure showed a gradual increase in the activity of the enzyme but showed a decline after attaining the optimal $\mathrm{pH}$ activity at $\mathrm{pH}$ 7.0.

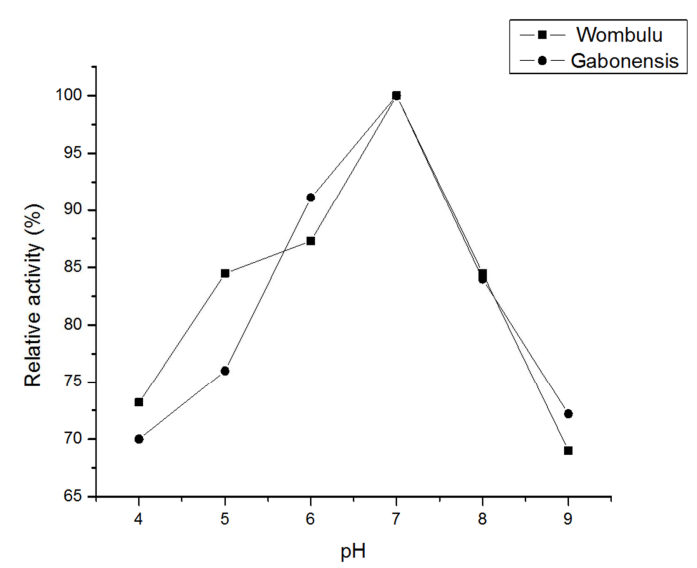

Figure 3. Effect of $\mathrm{pH}$ on the activity of Polyphenol oxidase from Irvingia gabonensis and Irvingia wombolu

\subsection{Thermal Stability}

The effect of temperature on the stability of polyphenol oxidase from Irvingia gabonensis is illustrated in figure 4a, while that of Irvingia wombolu is illustrated in figure $4 \mathrm{~b}$. The enzyme in both figures showed a $100 \%$ Relative activity at 25,30 and $60^{\circ} \mathrm{C}$. A very high relative activity of above $90 \%$ was observed both species at $40^{\circ} \mathrm{C}$ and $50^{\circ} \mathrm{C}$. The enzyme was not stable at $70^{\circ} \mathrm{C}$ and $80^{\circ} \mathrm{C}$ showing a relative activity of 35 and $12 \%$, and $35 \%$ and $15 \%$ for gabonensis and wombolu respectively after 1 hour incubation period.

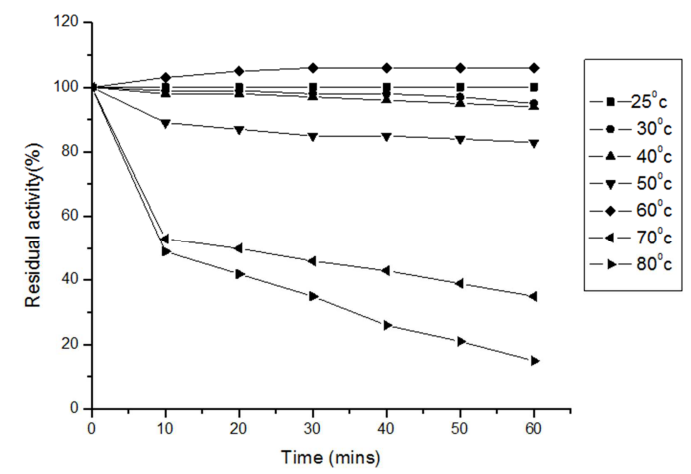

Figure 4a. Thermal stability of polyphenol oxidase from Irvingia gabonensis. The activity of the enzyme was expressed relative to the activity of the enzyme at 0 minutes taken at $100 \%$.

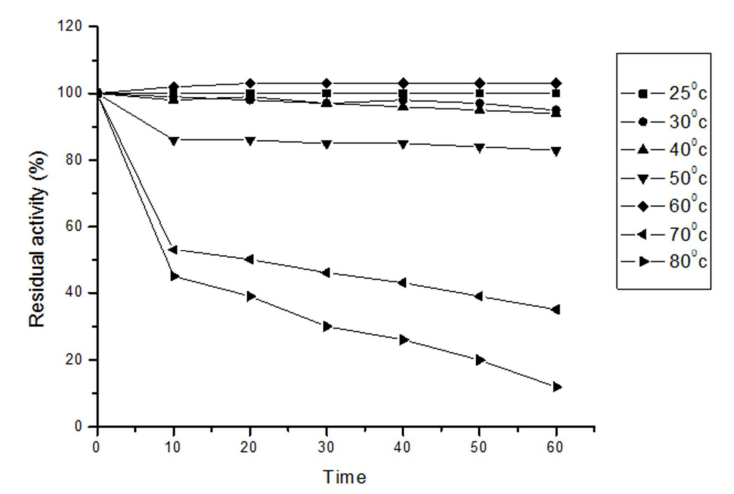

Figure $4 \boldsymbol{b}$. Thermal stability of polyphenoloxidase from Irvingia wombolu. The activity of the enzyme was expressed relative to the activity of the enzyme at 0 minutes taken at $100 \%$. 


\subsection{Effect of pH on the Stability of Polyphenol Oxidase}

The influence of $\mathrm{pH}$ on the stability of polyphenol oxidase from Irvingia gabonensis and Irvingia wombolu are shown in figures $5 \mathrm{a}$ and $5 \mathrm{~b}$. The enzyme from both Irvingia spp was very stable at $\mathrm{pH} 7.0$ with $100 \%$ relative activity after 6 hours of incubation period. The two enzymes were also fairly stable at $\mathrm{pH} 8,6$ and 5 showing a relative activity of 70 and $68 \%$, 52 and $83 \%$, and 70 and $50 \%$ for Irvingia gabonensis and wombolu respectively. However, there was a drastic decline in activity of the enzymes at $\mathrm{pH} 4$ and 9 showing a relative activity of 10 and $7 \%$, and 4 and $7 \%$ respectively for Irvingia gabonensis and wombolu.

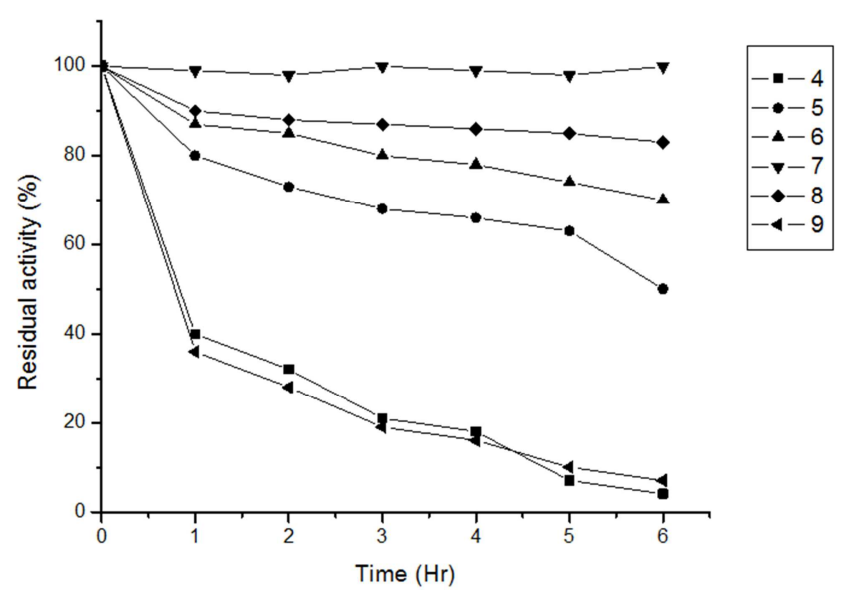

Figure 5a. $p H$ stability of Irvingia gabonensis polyphenoloxidase. The activity of the enzyme was expressed relative to the activity of the enzyme at 0 minutes taken at $100 \%$.

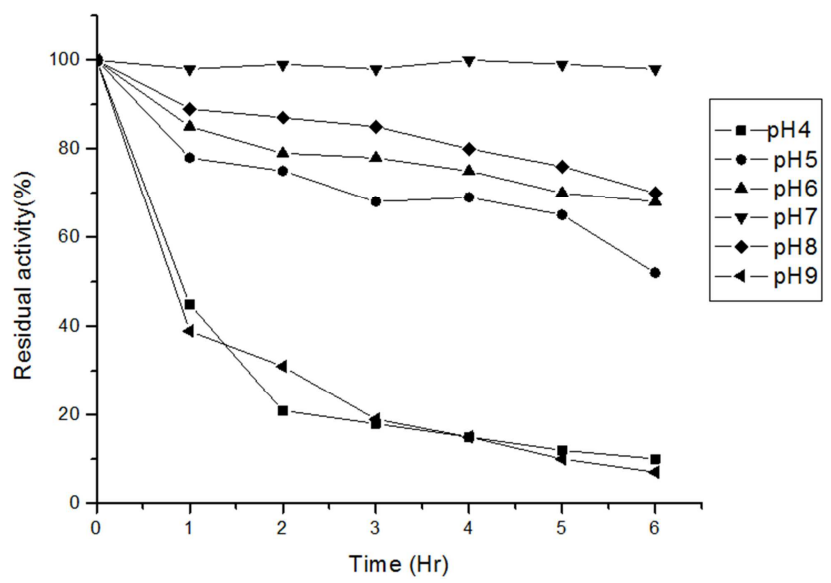

Figure 5b. pH stability of Irvingia wombolu polyphenoloxidase. The activity of the enzyme was expressed relative to the activity of the enzyme at 0 minutes taken at $100 \%$.

\subsection{Substrate Specificity}

The oxidizing ability of the partially purified polyphenol oxidase from the two Irvingia spp as shown in figure 6 was determined using tyrosine as monophenol and L-DOPA as the diphenol. Polyphenol oxidase from Irvingia wombolu and gabonensis showed a higher relative activity of $100 \%$ and $83 \%$ toward L-DOPA compared to 10 and $13 \%$ relative activity toward tyrosine.

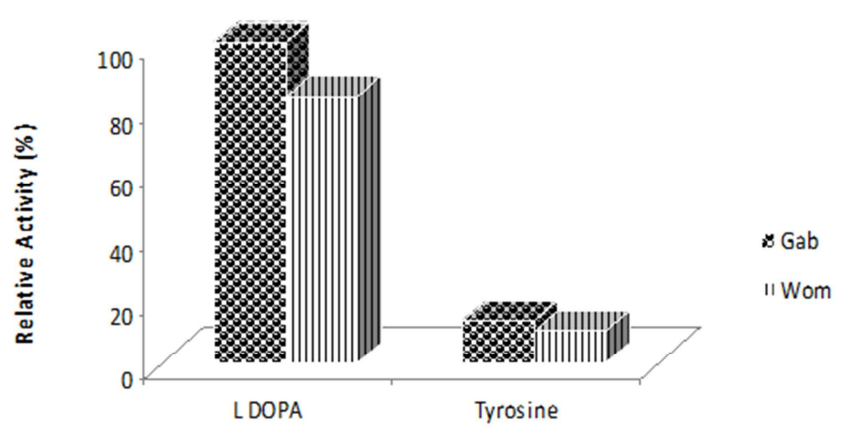

Substrate

Figure 6. Activity of the enzyme using a model monophenol and diphenol. The figure shows the activity of polyphenol oxidase of Irvingia species using tyrosine and L-DOPA as substrates.

\subsection{Kinetic Study}

The lineweaver- burk plots analysis of this enzyme showed Michaelis constant $\left(\mathrm{K}_{\mathrm{m}}\right)$ values of $2.51 \mathrm{mM}$ and $2.55 \mathrm{mM}$, while maximum rate $\left(\mathrm{V}_{\max }\right)$ values of $0.0411 \mathrm{Unit} / \mathrm{min}$ and $0.0415 \mathrm{Unit} / \mathrm{min}$ for Irvingia gabonensis and Irvingia wombolu polyphenol oxidase respectively.

\section{Discussion}

The result obtained indicated the presence of polyphenol oxidase in Irvingia gabonensis and Irvingia wombulu, with Irvingia wombulu specie showing more polyphenol oxidase activity than Irvingia gabonensis species. Several authors had reported the occurrence of polyphenol oxidase in plants; cucumber [23], grape [4], pineapple [6], mango [28]. Polyphenol oxidase is said to be involved in advance browning of plant products which generally causes deterioration in food quality by affecting its colour, flavour, texture and nutritional value [21]. It is a limiting factor in the processing of crops as peeled, sliced or injured crops rapidly undergo browning. The occurrence and wide distribution of polyphenolic and monophenolic compounds and their derivatives in almost all plant tissues is probably the underlying reason for the presence of this enzyme in plants [22]. The level of polyphenol oxidase activity of a particular plant species is inextricably connected to physiological needs of the plant. It has been reported that plants which possess relatively high levels of polyphenol oxidase activity are less susceptible to fungi and bacteria infections. This is obviously connected to the bacteriostatic properties of the brown products or pigments (melanin) of the enzyme action [21].

A wide range of $\mathrm{pH}$ optima for the activity of polyphenol oxidase ranging from $\mathrm{pH} 4.0$ [26] in field bean seed to $\mathrm{pH} 8.5$ [30] in Ginkgo biloba leaves had been reported in literature. The enzyme from the two species had optima activity at $\mathrm{pH}$ 7.0. This reveals that it is more active in a neutral $\mathrm{pH}$. Some plants unlike Irvingia species show optimum $\mathrm{pH}$ in the acidic region; $\mathrm{pH} 4.5$ for cherry and strawberry with methylcatechol 
as substrate [10], $\mathrm{pH} 3.5-4.5$ for apple and grape [20]. Several fruits including almond, apricot, peach and plum have been reported to show a general polyphenol oxidase optima $\mathrm{pH}$ around $\mathrm{pH} 5.0$ [10]. However, polyphenol oxidase from subtropical fruits such as longan and pineapple is most active near neutral $\mathrm{pH}[6,14]$. The $\mathrm{pH}$ optima from the two species of Irvingia is comparable to $\mathrm{pH} 7.5$ reported by Lima et al., [18] for immature, unripe fruit of soursop and $\mathrm{pH} 7.0$ for fully ripe fruits. Dogan et al., [7] and Gomes et al., [11] had also reported $\mathrm{pH}$ optima of 7.5 for aubergine, and 7.2 for beans polyphenol oxidase respectively. The changes in ionization of prototropic groups in the active site of an enzyme at lower acid and higher alkali $\mathrm{pH}$ values may prevent proper conformation of the active site, binding of substrates, and or catalysis of the reaction [37]. In addition, irreversible denaturation of the protein and or reduction in stability of the substrate as a function of $\mathrm{pH}$ could also influence the catalytic activity of enzymes [39].

Temperature is a very important factor that significantly influence the catalytic activity of polyphenol oxidase, as a decrease in temperature decreases kinetic energy and hence a low reaction rate [16]. Temperature optima as low as $20^{\circ} \mathrm{C}$ for bartlet pear [32] and as high as $60^{\circ} \mathrm{C}$ for Thermomyces lanuginosus has been observed [2]. An optima activity of $60^{\circ} \mathrm{C}$ observed in both Irvingia spp is high compared to the temperature optima of between $20^{\circ} \mathrm{C}-60^{\circ} \mathrm{C}$ generally observed for various plants using different substrate by Yoruk and Marshall [39] in his review of plant polyphenol oxidase. Yoruk and Marshall [39] however noted that optimum temperature of polyphenol oxidase varies in different plant sources and that nature of the substrate influences the optimum temperature. Irvingia spp polyphenol oxidase optimum temperature is higher than the $50^{\circ} \mathrm{C}$ observed in strawberry using pyrocathechol, cucumber using catechol [23] and $55^{\circ} \mathrm{C}$ observed in a thermophilic fungus Chaetomium thermophile [13].

The enzyme from the two species of Irvingia was thermally stable at $25^{\circ} \mathrm{C}, 30^{\circ} \mathrm{C}$ and $40^{\circ} \mathrm{C}$ while over $80 \%$ residual activity was observed at $50^{\circ} \mathrm{C}$ and less than $15 \%$ residual activity at $80^{\circ} \mathrm{C}$. It demonstrated a higher thermal resistant when compared with Artichoke heads [3]. Polyphenol oxidases from different sources exhibit different heat resistance. Welsche-Ebeling and Montgomery [36] reported that to inhibit $99 \%$ strawberry polyphenol oxidase activity 4, 5 and 6 minutes heating was necessary at 95, 90 and $80^{\circ} \mathrm{C}$ respectively while at $70^{\circ} \mathrm{C}, 7$ minutes heating was required to inhibit about $80 \%$ activity. Wakayama [35] also observed about 1.4 minutes to 2.4 minutes were required for $90 \%$ inhibition of the polyphenol oxidase from the core of six Japanese apple varieties.

The enzyme showed a higher catecholase activity and a very low cresolase activity. Polyphenol oxidase generally showed differences in activity for diphenol and monophenol substrate. Polyphenol oxidase from some seeds such as field bean seed [26] and sunflower seed [27] showed activity toward only odiphenol while activity of polyphenol oxidase from apple on monophenol (tyrosine) is much lower than on o-diphenols. The
Michealis-menten constant $\left(\mathrm{K}_{\mathrm{m}}\right)$ and maximum velocity $\left(\mathrm{V}_{\max }\right)$ showed a low degree of interspecies variability.

\section{Conclusion}

The results from the present study demonstrated that the two species of African mango seeds contained significant polyphenol oxidase activity. The optima $\mathrm{pH}$ and temperature for polyphenol oxidase activity were found to be 7.0 and $60^{\circ} \mathrm{C}$ from both Irvingia spp. The thermal stability studies show that the enzyme from both Irvingia gabonensis and Irvingia wombolu were $100 \%$ relatively stable at 25,30 and $60^{\circ} \mathrm{C}$ after 1.0 hour incubation period, while the $\mathrm{pH}$ stability studies of the enzyme from both Irvingia spp was 100\% relatively stable at $\mathrm{pH} 7.0$ after 6.0 hours incubation period. The enzyme show higher relative activities of $100 \%$ and $83 \%$ toward L-DOPA and lower relative activities of $10 \%$ and $13 \%$ toward tyrosine for Irvingia wombolu and gabonensis respectively. The kinetic studies of the enzyme show $\mathrm{K}_{\mathrm{m}}$ and $\mathrm{V}_{\max }$ values to be $2.51 \mathrm{mM}$ and $0.0411 \mathrm{Unit} / \mathrm{min}$, and 2.55 $\mathrm{mM}$ and $0.0415 \mathrm{Unit} / \mathrm{min}$ for Irvingia gabonensis and Irvingia wombolu respectively. Therefore, to extend the shelf-life of African mango seeds the enzyme (polyphenol oxidase) can be inactivated by brief heating to attain a temperature of $70^{\circ} \mathrm{C}$ above or $\mathrm{pH}$ adjustment.

\section{References}

[1] Agbor, L. O. N. (1994). Marketing trends and potentials for Irvingia gabonensis products in Nigeria. ICRAF-IITA Conference on Irvingia gabonensis; Ibadan, Nigeria.

[2] Astarc1, E. (2003). M. S., Department of Biotechnology the graduate school of natural andapplied sciences of the Middle East technical university.

[3] Aydemir, T. (2004). Partial purification and characterization of polyphenol oxidase from Artichoke (Cynara scolymus L.) heads. J. Food Chem. 87: 59-67.

[4] Cash, J. N., Sistrunk, W. A and Stutte, C. A. (1976). Characteristics of Concord grape polyphenol oxidase involved in juice colour loss. J. Food Sci. 41: 1398-1402.

[5] Coseteng, M. Y and Lee, C. Y. (1987) Changes in apple polyphenoloxidase and polyphenol concentrations in relation to degree of browning. J. Food Sci. 52: 985-989.

[6] Das, J. R., Bhat, S. G. and Gowda, L. R. (1997). Purification and characterization of a polyphenol oxidase from the kew cultivar of India pipeapple fruit. J. Agric. Food Chem. 45: 2031-2035.

[7] Dogan, M., Aralan, O., and Dogan, S. (2002). Substrate specificity, heat inactivation and inhibition of polyphenol oxidase from different aubergine cultivars. Intl. J. of Food Sci. and Tech. 37: 415-423.

[8] Ejiofor, M. A., Okafor, J. C. and Onwubuka, S. M. (1987). Developing improved methods of processing and utilization of kernels of Irvingia gabonensis var gabonensis and var excels. Journal of International Tree Crops, 14: 283-290. 
[9] Ejiofor, M. A. N. (1994). Nutritional values of Ogbono (Irvingia gabonensis var. excelsa). ICRAF-IITA Conference on Irvingia gabonensis; Ibidan, Nigeria.

[10] Fraignier, M., Marques, L., Fleuriet, A., Macheix, J. (1995). Biochemical and immunochemical characteristics of polyphenol oxidase from different fruits of Prunus. J. Agric. Food Chem. 43: 2375-2380.

[11] Gomes, M. R. A, Oliviera, M. G de A., Carneiro G. E. S, Barros E. G de and Morreira M. A., (2001). Physio-chemical properties of polyphenol oxidase from beans (Phaseolus vulgaris L.) Ciencia e Tccnologia de Alimentos. 21: 69-72.

[12] Hill, H. Z, (1992). The function of melanin or size blind people examine an elephant. Bio Essays 14: 49-56.

[13] Ishigami, T., and Yamada, Y. (1988). Characterization of polyphenoloxidase from Chaetomium thermophile, a thermophilic fungus, Journal of General and Applied Microbiology 34: 401-407.

[14] Jiang, Y. (1999). Purification and some properties of polyphenol oxidase of longman fruit. Food Chem. 66: 75-79.

[15] Kim, J., Marshall, M. R. and Wei, C. (2000). Polyphenol oxidase. In seafood enzymes utilization and influence on postharvest seafood quality, (N. F. Haard and B. K. Simpson, eds.), New York. 271-315.

[16] Laidler, K. J. and Peterman, B. F. (1983). Temperature effects in enzyme kinetics. In Contemporary Enzyme kinetics and Mechanisn (D. L. Purich, ed), 149-171.

[17] Leakey, R. and Newton, A. (1994). Domestication of tropical trees for timber and non -timber products. MAB Digest 17: $67-68$.

[18] Lima de O. S, Barbosa G. N., Sucupira M. T. and Souza L. A. V. (1994). Polyphenols concentration and browning intensity during soursop (Annona muricata L.) maturation. J. of Food Sci., 59: 1050-1052.

[19] Lowry, O. H., Rosebrough, N. J., Farr A. L. and Ran-dall, R. J. (1951). "Protein Measurement with Folin Phenol Reagent," Journal of Biological Chemistry 193: 265-275.

[20] Marques, L., Fleuriet, A. and Machiex J. (1995). Characterization of multiple forms of polyphenol oxidase from apple fruit. Plant Physiol. Biochem. 33: 193-200.

[21] Martinez, M. V. and Whitaker, J. R. (1995). The biochemistry and control of enzymatic browning. Trends Food Sci. Technol. 6: $195-200$

[22] Mayer, A. M. and Harel, E. (1979) Polyphenol oxidases in plants. Phytochemistry 18: 193-216.

[23] Miller, A. R., Kelley, T. J. and Mujer, C. V. (1990) Anodic peroxidase isoenzymes and polyphenol oxidase activity from cucumber fruit: tissue and substrate specificity. Phytochemistry 29: 705-709.

[24] Okafor, J. C. (1975). Varietal delimitation in Irvingia gabonensis (Irvingia ceae). Bulletin du Jardin Bota nique National de Belgique 45(1-2): 211-221.

[25] Onyeike, E. N. (1995). Effect of heat-treatment and defatting on the proximate composition of some Nigerian local soup thickeners. J. Food Chemistry 53: 2.173-175.

[26] Paul, B. and Gowda, L. R. (2000). Purification and characterization of a polyphenol oxidase from the seed of field bean (Dolihos lablab). Journal of Agriculture and Food chemistry 48: 3839-3846.

[27] Raymond, J., Rakariyathan, N. and Azanza, J. L. (1993). Purification and some properties of polyphenol oxidase from sunflower seeds. Phytochemistry 34: 927-931.

[28] Robinson, S. P., Loveys, B. R. and Chacko, E. K. (1993). Polyphenol oxidase enzymes in the sap and skin of mango fruit. Aust. J. Plant Physiol. 20: 99-107.

[29] Sanchez-Ferrer, A. Rodriguez-Lopez, J. N., Garcia-Canovas, F. Lavenda, F. and Garcia Camona, F. (1995). Tyrosinase: a comprehensive review of its mechanism. Biochem. Biophys. Acta 1247: 1-11.

[30] Seol, J. Y., Park, S. S. and Kim, A. K. (1999). Purification and some properties of polyphenol oxidase from Ginkgo biloba leaves. Korean Journal of Pharmacognosy 30: 306-313.

[31] Sherman, T. D., Vaughn, K. C. and Duke, S. O. (1991). A limited survey phytogenetic. Distribution of polyphenol oxidase. Phytochemistry 30: $2499-2506$.

[32] Siddiq, M. and Cash, J. N. (2000). Physio-chemical properties of polyphenol oxidase from D'Ánjo and Bartlett pears (Pyrus communis L.). J of Food pro. Pre. 24: 353-354.

[33] Vabi, M. B. and Tchamou, N. (1997). A farming systems perspective to non-wood forest product exploitation in the support zone of the Korup National Park of Cameroon: Determining the connections between the household and the forest. CARPE: Limbe non-wood forest roducts workshop.

[34] Vivien, J. and Faure, J. J. (1996). Fruitiers Sauvages d'Afrique.

[35] Wakayama, T. (1995). Polyphenol oxidase activity in Japanese apples. In: Lee CY, Whitaker JR. Enzymatic browning and its prevention. American Chemical Society, Washington. 251266.

[36] Wesche-Ebeling, P. and Montgomery M. W. (1990). Strawberry polyphenol oxidase: Purification and characterization J. Food Sci. 55: 1315-1319.

[37] Whitaker, J. R. (1995). Polyphenoloxidase. In Food Enzymes Structure and Mechanism, (D. W. S. Wong, ed.) Chapman and Hall, New York. 271-307.

[38] Whitaker, J. R. (1996). Polyphenoloxidase. In Food Chemistry, (O. R. Fennemaed.) Marcel Dekker, new York. 492-494.

[39] Yoruk, R and Marshall, M. R. (2003). Physicochemical properties and function of plant polyphenol oxidase. J. Food Biochem.68: 261-418.

[40] Zawistowski, J., Biliaderis, C. O. and Eskin, N. A. M. (1991). Polyphenoloxidase. In Oxidatives Enzymes in Foods, (D. S. Robinson and N. A. M. Eskins eds) Elsevier Science Publishing, New York. 217-273. 